\title{
Aproximación teórica a la violencia
}

\author{
Luis Armando González \\ Carmen Elena Villacorta
}

\section{Introducción}

Hablar de lo alarmante de la violencia en El Salvador se ha vuelto un lugar común. El gobierno y la empresa privada, tras varios años de silencio, han terminado por reconocer que la violencia es un problema nacional de primera importancia, que requiere ser tratado con el mayor detenimiento. Poco a poco se ha ido avanzando en la investigación cuantitativa del fenómeno; de hecho, ya se cuenta con las primeras cifras confiables acerca de su magnitud y costos económicos, lo cual, aunque restringido básicamente a los años de 1995 y
1996', abre las puertas a la elaboración de cálculos y series estadísticas que cubran años anteriores y posteriores, siempre y cuando sea posible recabar información primaria mínimamente consistente y/ o en la medida en que las instituciones estatales responsables -Fiscalía General de la República, Policía Nacional Civil, Ministerio de Justicia, etc.- hagan públicos los datos que vayan recabando sobre las diversas prácticas violentas que imperan en nuestra sociedad.

En otras palabras, la investigación cuantitativa de la violencia en El Salvador se halla, en la ac-

1. Ver número monográfico de la Revista ECA dedicado al tema "La cultura de la violencia en El Salvador", No. 588 , octubre, 1997. 
tualidad, bien encaminada. Obviamente, todavía quedan aspectos por resolver en la recolección y puesta al día de los datos; todavía no se resuelve -ni se tiene una explicación contundente de- la inconsistencia de las cifras of recidas por las distintas instituciones del Estado involucradas en la investigación y combate del crimen. Dicha inconsistencia se manifiesta, en no pocas ocasiones, en la discrepancia significativa de las cifras ofrecidas sobre un mismo rubro -digamos, por ejemplo, homicidios- durante un mismo período de tiempo. Se trataría, en este punto, de establecer no sólo la razón de la discrepancia, sino también la fuente (o fuentes) que habría que privilegiar a la hora de fundamentar los propios cálculos.

Tampoco está resuelta la pregunta por los criterios de clasificación (o tipificación) que orientan el trabajo de quienes rinden el informe inicial acerca de los diferentes hechos de violencia, y si esos criterios son compartidos por todos los que hacen similar trabajo en las diferentes instituciones del Estado involucradas en la problemática de la violencia.

Con todo, aunque se trata de dificultades importantes, éstas no son del todo insuperables a corto y mediano plazo. En consecuencia, es posible esperar que en la medida en que esas dificultades se vayan sorteando, las cifras oficiales sobre la violencia no sólo van a ir siendo más consistentes, sino que, además, van a ir estando más al alcance de aquellos investigadores interesados en utilizarlas para sus propias interpretaciones sobre la dinámica histórica y social salvadoreña.

Una vía de indagación sobre la violencia que se ha dejado de lado es la indagación teórica; es decir, la vía que nos ayude a comprender — más allá de las cifras sobre maltrato sexual, asaltos y homicidios, para mencionar sólo tres casos generalizados de violencia- cuál es el significado de la palabra "violencia", cuáles son sus variadas dimensiones, cuáles son sus raíces sociales, económicas, polílicas y psicológicas. La pregunta que engloba nuestra preocupación principal es la siguiente: ¿qué es la violencia? Pregunta aparentemente simple, pero de una complejidad asombrosa. La dificultad que lleva aparejada su respuesta ha llevado a muchos a desestimarla y a orientar sus esfucrzos hacia la recolección de datos sobre hechos "evidentes" de violencia, dejando para después —o para los teoricistas - la reflexión acerca de los, si se quicre, fundamentos de la violencia; en concreto, la reflexión sobre sus fundamentos sociopolíticos, económicos y psicológicos.

Se trata, entonces, de privilegiar no la recolección y sistematización de información sobre hechos de violencia - tarea de indudable importancia-, sino de discutir teóricamente cuáles son las razones que justifican el subsumir una serie de práclicas y comportamientos bajo la categoría "violencia". ¿Qué es lo común a esas prácticas y comportamientos? ¿Cuáles son las expresiones más importantes en las que eso común cobra realidad? ¿Dónde afinca la raíz última de eso común? ¿En la naturaleza humana (biológica y psicológica)? ¿En las estructuras económicas? ¿En el sistema social?

Esas preguntas encuentran diverso tipo de respuesta en las tradiciones de pensamiento sociológico y psicobiológico más importantes. En el campo de las primeras, nos interesa prestar atención a las inspiradas en el pensamiento marxista, así como a las que se pueden derivar de la teoría de sistemas de Niklas Luhmann. En el campo de las segundas, nos interesan las que más enfáticamente abordaron las raíces psicobiológicas de la violencia, es decir, las que nacieron principalmente en el marco de la escuela freudiana. Indudablemente, se trata de respuestas provisionales y, en consecuencia, discutibles en su conjunto o en algunos de sus componentes. Sin embargo, deben entenderse como un esfuerzo de clarificación teórica del problema de la violencia, complementario al esfuerzo de recolección de datos y elaboración de cálculos estadísticos que, por influjo de una marcada tendencia inductivista, predomina en la actualidad.

En estas páginas nos proponemos realizar una aproximación teórica al tema de la violencia, desentrañando lo que los autores citados $-\mathrm{y}$ otros que les sean afines-- puedan decirnos sobre éste. Antes de entrar en materia, empero, formularemos una definición provisional de la violencia - a manera de un tipo ideal weberiano- que nos sirva de hilo conductor a lo largo del desarrollo de estas reflexiones.

\section{Planteamiento teórico general}

La violencia puede ser entendida, en términos generales, como un ejercicio de fuerza de parte de instituciones, grupos o individuos sobre otros grupos o individuos con un propósito instrumental -obtener algo de quienes padecen el ejercicio de 
fuerza- y/o con un propósito expresivo - poner de manifiesto el poder y las convicciones del ejecutor de fuerza $a^{2}$. Como puede verse, se trata de una idea lo suficientemente amplia de la violencia como para englobar las concreciones más particulares de la misma; y, dentro de éstas, a esas dos formas de violencia que son las que más llaman la atención de la teoría sociológica: la instrumental y la expresiva.

Para entender más claramente qué es lo característico de ambas, veamos un texto de Fernando Savater sobre el tema. "Los sociólogos de la violencia - dice Savater- establecen una diferencia básica entre violencia instrumental (v. gr.: la del atracador que utiliza la pistola para atracar un banco) y la violencia expresiva ( $v$. gr.: la del fanático que asesina para demostrar la grandeza y sinceridad de su fe). La instrumental es la más fácil de controlar, pues para ello basta con ofrecer al violento por las buenas lo que aspira a conseguir por las malas, o con asegurarle un castigo cuya amenaza sea mayor que la recompensa que espera obtener. Pero quien se expresa por medio de la violencia realiza una apuesta incalculable, a fondo perdido, terroríficamente desinteresada y, por tanto, indomeñable"'.

Nuestra noción provisional de la violencia incorpora las dimensiones instrumental y expresiva aludidas por Savater, pero no circunscribe su aplicación a individuos y grupos, sino que lo amplía, sobre todo en uno de sus aspectos, a las instituciones. En efecto, éstas pueden ejercer, si es que no tienen como función específica hacerlo, la violencia instrumental ya sea para controlar desafíos de naturaleza política al orden social establecido, o ya sea para controlar y castigar las diversas violaciones a la legalidad —desde el irrespeto de las señales de tránsito hasta asesinatos- que cometen individuos y grupos en una sociedad determinada.

Asimismo, nuestra noción de violencia deja entrever otro elemento clave para su comprensión más cabal: la naturaleza (origen) de la violencia.

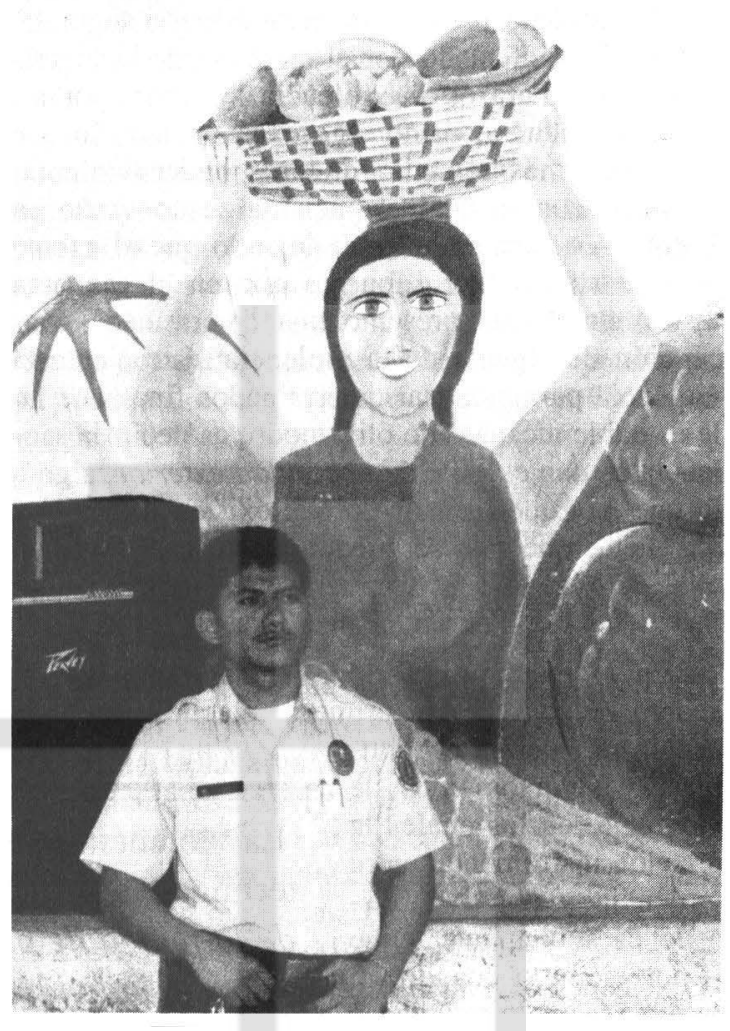

Esta, si nos fijamos en su dimensión instrumental, tiene no sólo un origen exterior a los individuos -ya sea porque son las instituciones las que la ejercen, desde fuera, sobre ellos, o ya sea porque son otros individuos (o grupos) los que lo hacen-. sino que a través de ella se consigue un bien más o menos determinado. Si nos fijamos en su dimensión expresiva, su origen es interior, es decir, es desde la realidad psicobiológica de los individuos que la violencia emerge, violentando a otros -quedando en la oscuridad el propósito instrumental de esa violencia-, pero violentando primariamente al sujeto que la lleva inscrita en su interioridad personal.

En otras palabras, si se toma como referencia

2. Para que no haya confusión, valgan las aclaraciones siguientes sobre los términos que componen esta noción de violencia. "Ejercicio de fuerza" no se refiere exclusivamente a la fuerza bruta, aunque la incluye, sino a cualquier afección física, social o individual sobre grupos o individuos; "propósito instrumental" se refiere a todas aquellas situaciones en las que la afección física (el componente de fuerza) sirve de instrumento (medio) para obtener un resultado preciso; "propósito expresivo" se refiere a todas aquellas situaciones en las que la afección física sobre otros pone de manifiesto ansias vitales, traumas o convicciones íntimas de quien (o quienes) la ejerce.

3. Fernando Savater, Diccionario filosófico, Barcelona: Planeta, 1995, p. 120. 
el eje agente-paciente en el examen de la violencia instrumental, el énfasis recae sobre el segundo: en el que es afectado por el ejercicio de la fuerza, la víctima. Para él, la violencia le viene, por así decirlo, de fuera, como algo exterior, ante lo que no queda más remedio que responder violentamente -con lo cual el paciente se convierte en agente- $o$ bien someterse, dejando que el agente alcance su fin. Por supuesto que en el esquema instrumental está presente una determinada concepción del agente de la violencia: éste ejerce la violencia para alcanzar determinados fines que no le es dable alcanzar de otro modo; es decir, la violencia es una especie de necesidad exterior, algo a lo que hay que recurrir porque existen determinadas metas que sólo se pueden alcanzar a través de ella, pero de la cual se podría prescindir si aquellas metas se pudiesen alcanzar por otros medios.

En el examen de la violencia expresiva, el acento recae sobre el primero: el que ejecuta la acción de fuerza, el victimario. Diversos tipos de violencia, en los cuales la relación instrumental entre violencia y objetivo buscado es sumamente tenue -por ejemplo cuando un sujeto asesina a puñaladas a una persona para arrebatarle un crucifijo- o absolutamente imposible de observar - por ejemplo, cuando un sujeto envuelve su cuerpo con explosivos y los detona en un centro comercial o una iglesia-, han obligado a volver la vista hacia el agente de la violencia y sus motivaciones conscientes o inconscientes. Desde aquí ha sido posible darle la debida importancia al agente de la violencia, el cual expresa a través de los más variados actos violentos, instrumentales y no instrumentales, tensiones y conflictos internos no siempre conscientes. En el esquema expresivo, aunque se privilegia al agente, hay una visión clara del paciente: este es ocasión para que se manifieste la violencia intrínseca del agente. Además, la violencia expresiva no excluye la instrumental, sino que la hace un momento suyo: aquél por el cual al agente, para realizar su propia carga de violencia, debe violentar a otros para obtener algo a cambio - un algo que puede obtenerse usando sólo la violencia que sea necesaria, o usando una violencia desproporcionada hasta niveles indecibles.

Por último, nuestra noción es tan amplia que permite establecer el rasgo común que poseen los tipos de violencia más conocidos y aceptados socialmente como tales - la mayor parte de ellos sancionados por los ordenamientos penales establecidos-, como otros que no desbordan ni de lejos el marco de la ley y, además, son aceptados por la sociedad, como las relaciones sexuales (normales) y la interacción comunicativa (normal) ${ }^{4}$. En estas situaciones existe un indudable componente de fuerza muy sutil y refinado, y también se hacen presentes en ellas los elementos instrumentales y/o expresivos.

Lo común no debe conducir a obviar las diferencias entre las diversas situaciones de violencia - por ejemplo, no es lo mismo una violación que una relación establecida por mutuo acuerdo, en tanto que en la primera el ejercicio de fuerza, el componente instrumental y la dimensión expresiva alcanzan una exacerbación tal que no existe en la segunda-, pero en aras de lograr una comprensión teórica del problema es legítimo establecer generalizaciones como la que hemos propuesto.

El examen de los aportes de las tradiciones marxista y psiconalítica nos ayudarán a aclarar y puntualizar aún más el planteamiento teórico general esbozado.

\section{El aporte del marxismo}

El tema de la violencia encontró, en la obra de Karl Marx, un tratamiento expreso; también la tra-

4. Añadimos "normales" para destacar que no se trata, en el caso de las relaciones sexuales, de violaciones o relaciones explícitamente forzadas; en el caso de las interacciones comunicativas no nos referimos a situaciones en las que el componente de fuerza también es explícito, como en el ejército o los gritos (órdenes) de un padre o una madre a los hijos, sino las conversaciones entre iguales. 
dición marxista posterior hizo énfasis sobre algunos de los tópicos tratados por Marx. El tratamiento que hace este autor del tema de la violencia se inscribe en el marco de su teoría de la alienación, cuya elaboración comenzó en los Manuscritos económico-filosóficos de 1844 y culminó en $E l$ Capital, su obra cumbres.

\subsection{Teoría de la alienación ${ }^{6}$}

En sus componentes esenciales, esta teoría se puede resumir como sigue: en el capitalismo, la burguesía, en virtud de la apropiación privada de los medios fundamentales de producción, se apropia de los bienes generados en el proceso productivo ${ }^{7}$. Estos se presentan ante quienes los producen - los trabajadores - como entidades ajenas, con una realidad propia a la que ellos deben de someterse.

Al decir de Marx, "si el producto del trabajo no pertenece al trabajador, si es frente a él un poder extraño, esto sólo es posible porque pertenece a otro hombre, que no es el trabajador... mediante el trabajo enajenado crea el trabajador una relación de este trabajo con un hombre que está fuera del trabajo y le es extraño... Partiendo de la Economía Política hemos llegado ciertamente al concepto de trabajo enajenado (...) como resultado del movimiento de la propiedad privada" ".

A partir de este principio generador de la enajenación econónica (la alienación fundamental), se derivan otras dinámicas de alienación como la jurídico-política (el Estado se autonomiza") y la ideológica (las ideas cobran vida propia ${ }^{11}$ ). Bajo el capitalismo, el conjunto de estas alienaciones permea la vida de los individuos, dando lugar a una felichización de las relaciones que éstos establecen entre sí.
En un texto ya clásico, Marx dejó escrito lo siguiente respecto del fetichismo: "si queremos encontrar una analogía a este fenómeno tenemos que remontarnos a las regiones nebulosas del mundo de la religión, donde los productos de la mente humana semejan seres dotados de vida propia, de existencia independiente, y relacionados entre sí y con los hombres. Así acontece con el mundo de las mercancías, con los productos de la mano del hombre. A esto es a lo que yo llamo el fetichismo bajo el que se presentan los productos del trabajo tan pronto como se crean en forma de mercancías""l!.

En Marx, pues, los individuos, bajo el capitalismo, no son dueños de sus creaciones, sean éstas económicas, jurídico-políticas o ideológicas; las mismas se les presentan en su vida práctica como entidades ajenas y dotadas de una lógica propia, externa a sus creadores. El mundo de las cosas termina imponiendo su ritmo al mundo humano, lo cual da lugar a una cosificación de las relaciones sociales, es decir, a que las relaciones sociales entre las personas no se presenten como tales en la conciencia de los actores, sino como "relaciones materiales entre personas y relaciones sociales entre cosas"12. En su origen, esa cosificación tiene de base la apropiación privada de los medios de producción por parte de una clase (la burguesía), la cual se sirve del aparato estatal y de la ideología - en el entendido de que la ideología dominante es la ideología de la clase económicamente dominante - para perpetuar su dominio económico.

En este sentido, la política y la ideología no sólo son ajenas a los individuos, sino que, en parte, esa enajenación es funcional a los intereses de la clase dominante: la ideología sirve de "ilusión" que hace creer que los cambios reales son resulta-

5. Para un balance de la teoría de la alienación en Marx, ver Gunzález. Luis Armando y Sermeño, Angel, $E l$ estatuto práxico de la teoría de la alienación de Marx. Tesis de Licencialura en Filosofía, San Salvador: UCA. 1988.

6. Podría parecer anacrónico volver a la teoría de la alienación de Marx; sin embargo, una respetable variante del marxismo actual —el marxismo analítico- considera que la misma es uno de los legados de Marx que aún tiene vigencia. Ver Elster, J., Una introducción a Karl Marx; México: Siglo XXI, 1991.

7. Para una visión de conjunto del pensamiento económico marxista, Ver Kühne, Karl, Economía y marxismo, México: Grijallbo. 1979.

8. Marx. Karl, Manuscritos: economía y filosofía, Madrid: Alianza, 1970, pp.114-116.

9. Ver Marx, Karl, La ideología alemana, La Habana: Pueblo y educación, 1982, pp. 33-34.

10. Ibid., pp. 48-49.

11. Marx, Karl, El Capital, México: FCE, 1972, p. 37.

12. Ibid., p. 38. 
do del cambio en las ideas; el Estado, como concreción privilegiada de la política, se presenta como garante formal del bien común y del interés general, cuando en realidad protege activamente los intereses de los propietarios de los medios de producción.

¿Qué hacer ante un mundo cosificado? Para Marx, la respuesta era clara: hay que subvertir revolucionariamente el orden social establecido, fundando un nuevo orden en el cual la propiedad privada de los medios de producción - fuente última de la alienación - sea abolida y reemplazada por la apropiación social de los mismos. Esa ingente tarea corre por cuenta de la clase que, de todas las existentes, tiene todo que ganar (la redención total) y nada que perder (pues se ha perdido incluso a sí misma) en el proceso de enajenación: la clase proletaria.

Eliminada la propiedad privada - piensa optimistamente Marx-, será factible encaminarse a la abolición de las alienaciones que de ella se derivan y, más aún, de la cosificación imperante en la sociedad capitalista en su conjunto. Pero, para eliminar la alienación económica, habrá que comenzar por dar la batalla a las alienaciones ideológica y política, pues de ésta saldrán los instrumentos para arribar a aquélla.

Una vez que la clase proletaria, organizada como es debido, se inserte en la dinámica apunta$\mathrm{da}$, el desenlace previsto -el fin de toda alienación y cosificación- estará asegurado. Se arribará al comunismo o "reino de la libertad": ese orden social en el cual "la libre individualidad, fundada en el desarrollo universal de los individuos y en la subordinación de su productividad comunitaria (...), social, como patrimonio social [se] subordinada a los individuos y controlada comunitariamente (...) como un patrimonio"'?. Se instauraría, así, una sociedad plenamente humanizada, una sociedad en la que llegará a su fin el trabajo impuesto por la necesidad externa ${ }^{14}$.

Muy apretadamente hemos resumido las tesis básicas de la teoría de la alienación de Karl Marx. Como veremos a continuación, sus reflexiones so-

13. Marx, Karl, Elementos fundamentales para la crít Siglo XXI, 1986, p. 85.

14. Ver González, Luis Armando, "El concepto de prax co-social, No. 19-2, enero-abril, 1991, pp. 195-226. bre la violencia se inscriben en el interior de sus planteamientos sobre la alienación porque, en definitiva, ésta, en sus diversas manifestaciones, expresa una situación de violencia que no puede soslayarse.

\subsection{Alienación y violencia}

En forma muy esquemática podemos resumir el problema de la violencia en la sociedad capitalista, según el planteamiento de Marx, a partir de los elementos siguientes: (a) la alienación económica supone la separación, por la violencia, entre los trabajadores y las condiciones de producción; (b) el aparato jurídico-político (cristalizado en el Estado) tiene como funciones fundamentales controlar coercitivamente los posibles desbordes de las clases subordinadas, o reprimirlos violentamente si se hacen efectivos; (c) las clases subordinadas pueden revertir la situación de despojo económico (alienación económica), para lo cual tienen que valerse de la violencia en dos sentidos: para desplazar del control del Estado a la clase dominante y para, desde el poder de estado recién conquistado, dar inicio a la recuperación por parte de los trabajadores de sus condiciones de producción; y $(d)$ toda forma de violencia llegará a su fin una vez que los vestigios de las formas de dominación económica del viejo orden (el orden burgués) sean erradicados totalmente; es decir, cuando se instaure la sociedad comunista.

El conjunto de esos aspectos resume el planteamiento de Marx sobre la violencia. Detengámonos someramente en cada uno.

(a) La alienación económica da pie a lo que en discusiones sociológicas posteriores se dio en llamar violencia estructural. Se trata de un tipo de violencia que hunde sus raíces en la estructura económica de la sociedad y que consiste, como señalamos antes, en el despojo que padecen los trabajadores de sus condiciones de producción. Este despojo se inserta, para Marx, en el proceso a partir del cual se constituye la sociedad capitalista: la acumulación originaria de capital. En efecto, en su desarrollo, el trabajador directo es separado me-

de la economía política (Grundrisse), Vol. 1, México: n Marx: la unidad de ética y ciencia", Realidad económi- 
diante la fuerza (estatal y privada) de sus condiciones de trabajo y reproducción, especialmente la tieпra. Y ello porque esa separación es el supuesto necesario para el surgimiento de una mano de obra libre, es decir, dispuesta a venderse a cambio del salario ofrecido por los empleadores capitalistas.

Los trabajadores, pues, son alienados de sus condiciones de trabajo. Ello sucede a través del uso de la fuerza, cuyos niveles pueden ser tan elevados como elevada sea la resistencia de aquéllos. Además, esta violencia estructural no se agota en el proceso en el que nace la sociedad capitalista, sino que se mantiene como requisito suyo a medida que ésta se expande y consolida. Esto sucede porque la clase privada de sus condiciones de producción - la clase trabajadora - vive permanentemente padeciendo las consecuencias del despojo de la que fue objeto, lo cual se expresa en su condición de pobreza y marginalidad socioeconómica. Es decir, el despojo de sus condiciones de producción condena a la clase proletaria, mientras esa separación no sea erradicada, a la pobreza y la deshumanización más absolutas ${ }^{15}$. Esta es la realidad que expresa, en la tradición de pensamiento marxista, el término violencia estructural.

(b) Los trabajadores fueron separados de sus condiciones de trabajo, principalmente debido a la fuerza del Estado, por la utilización de determinados mecanismos de coerción estatales, entre los cuales los mas relevantes son la policía y los tribunales. Una vez operada la separación señalada, la policía y los tribunales ejercen su rol de vigilantes del orden establecido, y asumen un papel abiertamente represivo toda vez que las clases subalternas lo perturben, ya sea instintiva o conscientemente. En este sentido, la función del Estado consiste en ser instrumento de dominio de la clase burguesa sobre las demás clases, en el entendido de que el Estado es tanto una "máquina para mantener el dominio de una clase sobre otra"16 como "la forma bajo la que los individuos de una clase dominante hacen valer sus intereses comunes y en la que se condensa toda la sociedad civil de una época"17.

Del Estado emerge una violencia política, que se ejerce sobre todos aquellos -incluidos miembros de la misma burguesía- que perturban el orden establecido. Esa perturbación puede obedecer a resentimientos de clase, a una resistencia instintiva a la dominación - la cual se puede manifestar en diferentes hechos de violación a la legalidado a un movimiento consciente del proletariado en busca de derribar el poder burgués. En este último

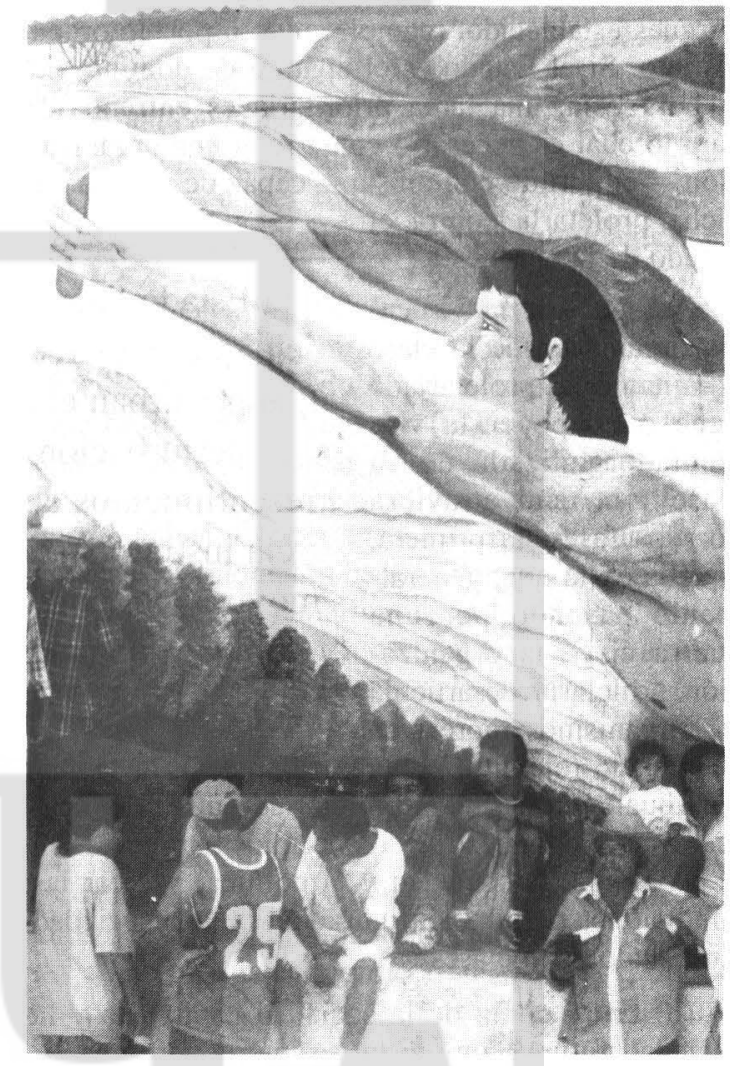

15. Sobre la degradación del obrero en el capitalismo, ver Marx, Karl, "Salario, precio y ganancia", en Obras escogidas, Moscú: Progreso, p. 225 y ss. El lumpenproletariado, integrado por los mendigos, ladrones, trabajadores itinerantes, cómicos, burgueses proscritos, tahúres, libertinos y prostitutas, también es un subproducto de la miseria humana generada por el capitalismo. Ver Collins, Randall, Cuatro tradiciones sociológicas, México: UAM, 1996, p. 69.

16. Lenin, V.I., "Acerca del Estado", en Obras escogidas, Vol. III, Moscú, p. 265.

17. Marx, Karl, La ideología... p. 69. Entre la amplia bibliografía existente sobre el tema, otras ideas interesantes sobre el problema del Estado en Marx se pueden encontrar en Nicos Poulantzas, Poder político y clases sociales en el Estado capitalista, México: siglo XXI, 1973; también en Biagio de Geovanni, "Marx y el Estado", en AAVV, Teoría marxista de la política, México: Pasado y presente, 1981, pp. 28-68. 
caso es cuando la violencia política se vuelve totalmente explícita, pues los aparatos de coerción del Estado - y en muchas ocasiones las milicias privadas de los sectores dominantes- ponen en práctica medidas de fuerza legales e ilegales (dentro de éstas es usual el terrorismo de Estado) para contener el ascenso del proletariado.

(c) A la violencia estatal, la clase proletaria no tiene más remedio que responder —una vez que ha cobrado conciencia de la situación-con una dosis igual o superior de violencia. Se trata de una violencia revolucionaria, puesto que su sentido último estriba en trastocar radicalmente el orden burgués establecido, reemplazándolo por un orden distinto. Si el Estado es el aparato de dominio de la burguesía, una tarea prioritaria es enfrentarlo, para lo cual es necesario contar con una organización —el partido comunista - capaz de orientar la lucha proletaria contra el

Estado de la burguesía.

Así pues, a la violencia organizada de la clase dominante, el proletariado tiene que oponer la violencia organizada de su clase $^{\text {ik}}$, la cual atraviesa por dos fases: la primera, aquélla en la que, generalmente pasando por una guerra civil, la organización proletaria desarticula los organismos represivos del Estado (ejército, policía, tribunales); la segunda, aquélla en la que el proletariado utiliza el aparato estatal para destruir los resabios burgueses (en la economía, la sociedad y la política) y crear las condiciones para la configuración de una sociedad $\sin$ Estado y sin clases $^{14}$.

(e) Entre el fin de la sociedad capitalista y la sociedad futura, comunista, se interpondrá una situación intermedia de "transición", conocida como la "dicladura revolucionaria del proletariado" 20 . En esta elapa se ejercerá la violencia política, cuyo objetivo preciso será erradicar los vestigios del antiguo régimen. A la misma le será intrínseca la transitoriedad, es decir, el estar diseñada para llegar a su fin una vez que su objetivo haya sido cumplido. Llegado este momento, no sólo desaparecerá la violencia política, sino todas las formas de violencia existentes.

La violencia política del proletariado, una vez instalada su dictadura, será una violencia usada para erradicar las violencias fundamentales en el capitalismo: la violencia política, pues no existirán las clases; la violencia económica, pues habrá desaparecido la alienación económica cuando los trabajadores recuperen sus condiciones de producción. En palabras de V.I. Lenin: "nosotros proponemos como meta final la abolición del Estado, es decir, de toda violencia sistemática y organizada, contra todo el uso de la violencia contra el hombre en general... Pero, aspirando al socialismo, estamos persuadidos de que se convertirá gradualmente en comunismo y en relación con esto desaparecerá toda necesidad de violencia sobre los hombres en general, toda necesidad de subordinación de unos hombres a otros, y de una parte de la población a otra, pues los hombres se habituarán a observar las reglas elementales de la convivencia social sin violencia y $\sin$ subordinación"'2!.

Como podemos ver, el tratamiento del tema de la violencia en la tradición marxista pone de relieve su dimensión instrumental. En primer lugar, la violencia que se ejerce en el despojo de la acumulación originaria tiene como objetivo separar a los trabajadores de sus condiciones de producción; la que se ejerce desde el Estado tiene como propósito ya sea

18. Para Marx se trata de una violencia organizada y consciente, es decir, fundada en el conocimiento científico de la realidad. Aquí es oportuno citar a G. Sorel, quien fue uno de los intelectuales que insistió, en sus Reflexiones sobre la violencia (1905), en las fuentes irracionales (míticas) de la violencia revolucionaria.

19. Para una valoración crítica de la teoría del conflicto político en Marx, ver Collins, Randall, op. cit., pp. 75-83.

20. Marx, Karl, “Crítica al programa de Gotha”, en Obras escogidas, Moscú: Progreso, p. 342.

21. Lenin, V.I.. El Estado y la revolución, Moscú: Progreso, 1976, p. 78. 
controlar posibles brotes de resistencia antisistema, o reprimirla cuando se hace efectiva. En ambas situaciones, además, se utilizan mecanismos diseñados ex profeso para ejercer la violencia: los cuerpos armados y los tribunales. Estos, además, suelen racionalizar el ejercicio de la violencia, es decir, buscan no sólo minimizar sus costos de funcionamiento, sino maximizar su efecto coercitivo.

En segundo lugar, la violencia tiene una dimensión instrumental también para el proletariado. quien la ejerce, primero, para hacer frente al Estado burgués, $y$, después, para poner en marcha el proceso de socialización de las condiciones de producción. Sin una dosis de violencia, a las clases subordinadas les sería imposible desencadenar y llevar a feliz término el proceso de emancipación definitiva de la humanidad; es por ese fin que se legitima y justifica la violencia revolucionaria organizada.

En tercer lugar, el planteamiento marxista hace énfasis en la violencia como algo externo a los individuos. Sea como coerción-represión estatal, enajenación económica o lucha revolucionaria, la violencia es algo que se ejerce desde fuera sobre los individuos que la padecen, y algo que éstos ejercen sobre quienes iniciaron el ciclo de violencia para defenderse y revertir la situación. Se trata, entonces, de una externalidad a los individuos; de algo que viene de fuera $y$ que hay que combatir hacia afuera. Y lo que haya de violencia en el interior de la persona humana, al igual que otros componentes de su personalidad, tiene un origen exógeno. Por algo Marx llegó a asentar, con particular fuerza, en sus Tesis sobre Feuerbach (Tesis VI), que la esencia humana "es, en su realidad, el conjunto de las relaciones sociales".

En cuarto lugar, cabe destacar el optimismo marxista ${ }^{22}$ acerca del fin de la violencia. Este optimismo tiene su razón de ser, primero, en el historicismo de Marx y, segundo, en su visión de la violencia como un fenómeno eminentemente social. En el esquema de Marx, la historicidad no sólo hace transitorios los diversos fenómenos humanos, sino que también los inscribe en un proceso de humanización de largo aliento que condena a su desaparición a todo aquello que empaña la vida humana en el presente. Por otra parte, como fenómeno social, la violencia es una realidad objetiva exterior a los individuos, una realidad que éstos pueden domeñar, una vez conocidas sus fuentes y mecanismos, aplicando medidas de la más diversa naturaleza, entre las que no se excluye la utilización de la fuerza.

Finalmente, en el esquema marxista está presente una concepción terapéutica para hacer frente a la violencia. Mientras perdure la violencia estructural, las clases subalternas se van a revelar de diversas formas contra las clases dominantes; éstas, por consiguiente, van a tener que diseñar múltiples mecanismos para controlar (sin poder extirparlos nunca y de raíz) esos brotes de malestar social ${ }^{23}$. Las clases dominadas, mientras no llega la hora final de la violencia (el comunismo), van a tener que implementar diversas medidas -como la organización sindical, el cooperativismo, etc.encaminadas a hacer menos lacerantes las condiciones de explotación capitalistas. Pero sólo se tratará de medidas paliativas, puesto que las violencias estructural y política seguirán imponiéndose sobre ellos mientras perdure el sistema.

\subsection{Valoración crítica}

Si aceptamos que el esfuerzo teórico de Marx estaba dominado por un afán científico, debemos estar dispuestos a aceptar, también, a más de cien años de su muerte, la necesidad de revisar su legado sociológico, económico, histórico y político. Esta valoración debe estar encaminada a discernir

22. Marx logra articular de una forma discutible su visión estructural de la realidad social con su optimismo emancipatorio. La Escuela de Frankfurt, sobre todo de la mano de Habermas, ha intentado mantener la tensión entre ambos aspectos. Desde la teoría de sistemas de Lhumann, en muchos aspectos coincidente con la teorfa social habermasiana, se hecha por la borda ese optimismo, puesto que el sistema, con sus subsistemas coercitivos, no sólo se impone omnímodo sobre los individuos, sino que además camina hacia donde sus necesidades de reproducción se lo exigen, siendo los propósitos de emancipación sólo una vana ilusión. Ver González, Luis Armando, "Teoría crítica versus teoría de sistemas", Realidad, No. 41, septiembre-octubre, 1997, pp. 785-812.

23. Esta visión fue llevada, incluso, hasta la psiquiatría por autores italianos que vieron en ella "un instrumento de represión y de control de las posturas desviantes... [ una práclica que] pone las bases para una estrecha colaboración entre psiquiatría, jueces y policía". Jervis, G., Psiquiatría y sociedad, Caracas: Fundamentos, 1981, p. 39. También se puede consultar Franco Basaglia et. al., Los crímenes de la paz, México: Siglo XXI, 1981. 
sobre cuáles son aquellos aportes de Marx que aún tienen potencia explicativa de la realidad social y cuáles la han perdido o, al menos, deben ser reexaminados a la luz de los aportes de las ciencias sociales contemporáneas.

En lo que respecta al problema de la violencia, el aporte teórico de Marx es, en algunos de sus aspectos, de gran relevancia analítica. En primer lugar, su concepción de lo que es la violencia estructural, su origen y sus mecanismos perversos de funcionamiento constituyen un aporle de gran valor para el análisis de las sociedades latinoamericanas y africanas contemporáneas. Las distintas aproximaciones conceptuales al problema de la marginación socio-económica que se hacen en la actualidad, cuya pretensión científica es inobjetable, se remiten a las tesis de Marx sobre el tema de la violencia estructural.

En segundo lugar, como pocos autores, Marx supo desentrañar el sentido y los mecanismos de la violencia política, cuya relevancia en la dinámica de las sociedades capitalistas, desde los tiempos de Marx hasta bien entrado el siglo XX, es innegable. En América Latina, desde finales del siglo XIX hasta finales de los años ochenta, este tipo de violencia, tanto en su carácter estatal y paramilitar como en su carácter contestatario y popular, fue el eje central de la dinámica política. Incluso, en buena medida por el influjo del planteamiento marxista, se llegó a formular la idea del "espiral de la violencia". Idea que hacía alusión a la secuencia siguiente: violencia estructural (originaria) $\rightarrow$ violencia de resistencia instintiva (popular) $\rightarrow$ violencia institucional(estatal)->violencia organizada (popular)->represión estatal generalizada y terrorismo de Estado. En aquel entonces, era casi imposible lograr una comprensión medianamente clara de la realidad social latinoamericana - marcada por regímenes políticos autoritarios, economías excluyentes de la mayor parte de la población y movimientos sociales radicales- sin tomar en cuenta la lógica de la violencia que la regía.

En tercer lugar, en el tratamiento marxista de la violencia cobra relevancia su dimensión instrumental ${ }^{4}$. La violencia sirve para lograr determina- dos propósitos, ya sean éstos económicos o políticos; es decir, sirve de medio para alcanzar determinados fines. No es irrelevante para las ciencias sociales el que Marx haya puesto de relieve esta dimensión de la violencia y, más aún, que haya logrado establecer determinados tipos de violencia que se caracterizan por su instrumentalidad. Esta perspectiva analítica es un herramienta de valor en los estudios contemporáneos sobre violencia, los cuales han permitido identificar muchos más tipos de violencia instrumental -que se circunscriben en su gran mayoría al ámbito individual- que los contemplados por Marx.

En cuarto lugar, Marx puso de relieve el carácter objetivo de la violencia. En virtud de ello, la violencia no es algo que pueda estar sujeto a la mera voluntad humana, puesto que tiene una realidad allende ésta: en la base económica y en la superestructura jurídico-política. En el capitalismo, nos enseñó Marx, los individuos tienen que convivir, hasta que no se arribe al comunismo, con la violencia y sus mecanismos de funcionamiento. Tienen que vivir con la violencia que ejercen las clases dominantes, a través de la economía y la política, y la violencia que ejercen las clases subalternas para resistir la violencia de las primeras y preparar el advenimiento de una sociedad sin violencia.

Por último, junto con la idea de la objetividad de la violencia, Marx pone de relieve lo inexorable que es para los hombres vivir con ella, al menos mientras existan las sociedades divididas en clases. Si no nos dejamos arrastrar por el optimismo de Marx y asumimos que la sociedad idilica que él nos propone difícilmente será alcanzada en algún momento de la historia de la humanidad, entonces llegamos a la conclusión de que la violencia nunca será erradicada de la convivencia social. Es decir, que los seres humanos tendrán que aprender a vivir, ahora como en el pasado, con la violencia no como algo accidental, sino como algo inscrito en la estructura social. Si se suprime de Marx el elemento utópico, su planteamiento sobre la violencia viene a ser coherente con otras teorías sociales, para las cuales la misma es un componente ineludible e inextirpable de la vida social del hombre.

24. La violencia instrumental puede entenderse como parte del imperio que la racionalidad instrumental ejerce sobre la sociedad capitalista. Ver Heorkeimer, Max y Adorno, T.W., Dialéctica de la Ilustración, 1946; González. L.A., “Neoconservadores, postmodernos y teóricos críticos”, Metapolítica, No. 1, México, eneromarzo, 1997, pp. 72-81. 
De estas teorías, es pertinente traer a cuenta la teoría de sistemas elaborada por Niklas Luhmann ${ }^{25}$. Muy resumidamente ${ }^{26}$, los aportes teóricos de este autor constituyen una crítica y una renuncia a algunos de los valores más queridos de la Ilustración. De hecho, Luhmann pretende superar la Ilustración en un aspecto específico: la primacía que ésta otorga al sujeto, con la cual Luhmann se muestra en total desacuerdo. En efecto, éste pone entre paréntesis a la subjetividad humana en su estudio del sistema social. El individuo, como sujeto, queda fuera de las

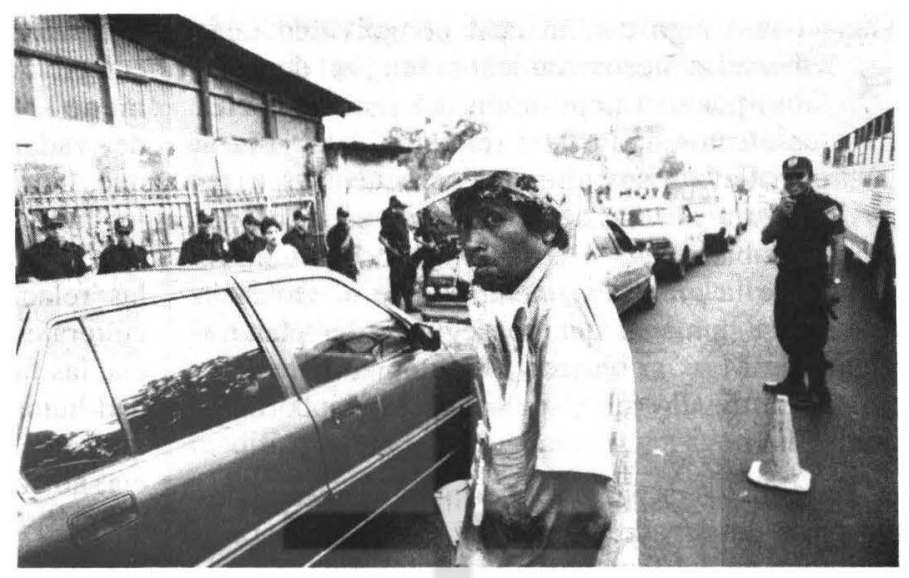
consideraciones luhmanianas a la hora de explicar a la sociedad: los sujetos son parte del entorno de la sociedad. Esta, como sistema, se autorreproduce en y por sí misma, sirviéndose de los elementos existentes en su entorno - la naturaleza, los individuos- con los cuales está en permanente pugna y poniendo en marcha todos aquellos mecanismos que le ayuden a tal propósito.

En Luhmann todo se explica por la relación sistema-entorno; justamente todo lo que no es sistema es entorno y viceversa. ¿Qué es un sistema? Todo aquello que posee capacidad de autopoiesis, esto es, capacidad de autorreproducirse y autoconservarse sirviéndose de los recursos del entorno. ¿Cuál es el sistema más complejo? El sistema social, y su complejidad se ve confirmada por el hecho de que es un sistema capaz de observarse a sí mismo. ¿A través de qué? A través de la teoría social.

¿Qué es la política para Luhmann? Es, ante todo, un subsistema del sistema social; un subsistema que le es funcional en la medida en que hace creer a los individuos que participan y deciden en la dinámica social. Pero esa participación y esa decisionalidad son una ficción; una fícción que, en tanto existe, dota al sistema social de legitimidad, evitando los conflictos y la inestabilidad. Hacer creer a los individuos que participan y deciden: esa es la función legitimadora del subsistema político, del que son parte las teorías políticas, en las sociedades del capitalismo tardío; el subsistema

político también tiene una función coercitiva que se pone en marcha en momentos de crisis de legitimidad del sistema.

En Luhmann, el sistema social lo es todo, los individuos nada. Estos están a merced de las demandas del sistema, cuyo funcionamiento obedece a sus propias necesidades de conservación y reproducción. Los individuos están condenados a vivir a la sombra de un sistema social, para el cual siempre serán recursos para satisfacer sus propias necesidades. Ello, además, nunca dejará de ser de otro modo, al menos hasta que el sistema social no se desintegre, lo cual es mucho más improbable que el advenimiento del comunismo. Como podemos ver, el sistema ejerce una violencia sistémica sobre los individuos, quienes deben perder toda esperanza de que eso pueda ser algún día de otro modo. No hay cabida aquí para optimismo alguno.

¿Y las violencias más concretas como, por ejemplo, los asaltos y la represión policial? Al igual que otros fenómenos sociales -como la pobreza, las hambrunas, la depredación del medio ambiente, etc.- existirán siempre que el sistema así lo requiera para sus propios fines, lo cual quiere decir que cualquier intento humano por disminuirlas o eliminarlas será vano.

Así pues, Luhmann deja asentadas una serie de tesis no por discutibles menos interesantes para el análisis social. Este autor nos hereda una visión deshumanizada de la violencia; es decir, de la vio-

25. Ver, Luhmann. N.. Sistemas sociales. Lineamientos para una teoría general, México: Alianza-Universidad Iberoamericana. 1991.

26. Ver. González, L. A., "Política y postmodernidad (Lyotard, Popper, Luhmann y Habermas)", ECA, No. 591592, enero-febrero, 1998, pp. 120-124. 
lencia como algo con lo cual el individuo tiene que habérselas necesariamente, no por decisión suya, sino por una imposición del sistema social. Para los efectos de nuestra reflexión sobre Marx, Luhmann lleva a sus últimas consecuencias la tesis de la exterioridad de la violencia asentada por aquél; también lleva a sus últimas consecuencias la tesis de la presencia ineludible de la violencia en la vida humana, que se seguiría del planteamiento de Marx si se acepta lo utópico (irrealizable) de un mundo feliz, sin violencia y subordinación.

En fin, los aspectos anteriormente señalados son parte del legado teórico del marxismo para la comprensión del fenómeno de la violencia. Se trala, por lo demás, de un aporte parcial, en cuanto a que él mismo deja de lado dimensiones de aquélla que fueron exploradas por otras tradiciones intelectuales. La pregunta que se impone es la siguiente: ¿qué es lo que quedó fuera de la consideración que Marx hizo sobre la violencia? Para responderla, vamos a señalar algunos de los déficit o puntos débiles del análisis marxista de la violencia.

En primer lugar, la confianza excesiva de Marx en la violencia (revolucionaria) para terminar con todo lipo de violencia. La experiencia histórica mostró, con las llamadas dictaduras del proletariado que se establecieron en el ex bloque del Este y la ex Unión de Repúblicas Soviéticas Socialistas, que los regímenes políticos que nacieron al calor de ellas llegaron para quedarse en el poder por un tiempo indefinido; tiempo durante el cual se ejercieron los más diversos tipos de violencia estatal que en lo absoluto estaban encaminados a erradicar la violencia, sino más bien a generar focos de resistencia antitotalitaria que terminaron dando al traste con los "socialismos reales". Tal vez Marx no se equivocó al señalar que una violencia (estructural y política) genera otra violencia encaminada a resistirla y a doblegarla; sí se equivocó quizás al creer que quienes doblegaban a los violentos utilizando la violencia iban a renunciar al monopolio de la misma.

En segundo lugar, el excesivo peso que tiene en Marx lo macro. Las categorías principales de su concepción - alienación económica, Estado, pro- letariado, violencia de clases, etc.- son de índole colectiva y macrosocial. La violencia es un fenómeno económico, social y polílico, y sólo derivadamente un fenómeno individual. No es que, como recordó en su momento Adam Schaff, los individuos estén ausentes en la concepción de Marx, pero su vida individual es la resultante de las relaciones sociales (políticas, económicas y culturales) que cristalizan en ella. En consecuencia, las fuentes de la contiguración de la personalidad humana están en la sociedad. Se entiende por qué, en el tratamiento que hace Marx de la violencia, no sólo quede excluido el individuo, sino que, además, se pongan de relieve sus características macrosociales y macropolíticas: la realidad histórica tiene como sujetos privilegiados a colectivos de los cuales el individuo es parte subordinada.

Esta perspectiva, en tercer lugar, impidió a Marx y a una buena parte de la tradición marxista posterior - la que siguió las sendas del marxismoleninismo- examinar no sólo los microfundamentos de la violencia, sino manifestaciones de la misma muy puntuales y dificiles de insertar en el marco contemplado por la violencia estructural y la violencia política. El examen de los microfundamentos $^{27}$ hizo volver la vista hacia los individuos, concebidos ya no como marionetas de la sociedad o como una cristalización de las relaciones sociales, sino como siendo en parte eso y en parte algo distinto: una realidad que, además de anclar sus raíces en la sociedad, tiene una filiación biológica (animal) includible, a cuya sombra se fraguan las más complejas conductas humanas y cuya lógica es difícil desentrañar.

El examen de diversas manilestaciones de violencia, más específicas que las contempladas en las relaciones de clase, revela que en muchas era casi imposible establecer el componente económico y político que las adscribiera a los marcos conceptuales de procedencia marxista. Asimismo, una gran gama de tipos de violencia se circunscriben a círculos de relaciones microsociales, en los cuales la acción-interacción individual cobra una preponderancia inocultable. Además, en ese ámbito microsocial a veces es relativamente fácil caracterizar un acto violento como instrumental, pero a

27. Por cierto, el giro hacia los microfundamentos ha sido asumido por una corriente del marxismo —el marxismo analítico- ahora en auge. Ver Roemer, J. E. (Comp), El marxismo: una perspectiva analítica. México: FCE, 1989. 
veces ello se vuelve totalmente imposible, pues no aparece por ninguna parte la relación medio-fin propia de la lógica instrumental.

Es preciso, entonces, recurrir a un marco conceptual distinto del marxista que nos encamine en la dirección que le estuvo vedada a Marx: la que apunta a la dimensión personal de la violencia; es decir, aquella violencia que hunde sus raíces en la individualidad humana y que expresa la dinámica psicobiológica propia de cada individuo.

\section{La tradición psicoanalítica}

Para una cabal comprensión del aporte teórico de Sigmund Freud es importante saber, primero, que el mismo surgió en un contexto marcado por el auge avasallador de la física de Newton y de la teoría evolucionista de Darwin; y, segundo, que el modelo explicativo freudiano hunde sus raíces en la medicina, la neurología y la biología. La distinción entre consciente, preconsciente e inconsciente y la división de la psique en ello, yo y super-yo son aspectos fundamentales de la teoría de Freud. Sin embargo, el objeto del presente trabajo nos exige concentrarnos únicamente en el área en la que el autor se ocupó de lo que en psicología freudiana se conoce como agresión. Y esa área es la teoría de los instintos.

\subsection{La teoría de los instintos de Sigmund Freud}

Un recuento preciso y muy claro acerca de cómo Sigmund Freud llegó a valerse de la pugna entre Eros -instinto de vida - y Tanatos -instinto de muerte - para explicar el comportamiento humano se encuentra en la obra Introducción al conocimiento de Freud, de Benjamin B. Wolman ${ }^{2 \mathrm{H}}$. Con el fin de hacer una aproximación general a la teoría freudiana de los instintos, expondremos brevemente el planteamiento de Wolman.

Antes que nada, hay que decir que dentro del marco de referencia de Freud, la inercia es la ley básica; los cuerpos son inertes mientras no se expongan a las fuerzas que causan el movimiento. Las fuerzas que animan a la naturaleza orgánica reciben el nombre de impulsos — traducido muchas veces como impulsos instintivos o instintos. De acuerdo con la concepción freudiana, estos impulsos son hereditarios y tienen por objeto la conservación de la vida individual y la conservación de la especie. Hasta 1914, Freud denominaba a los primeros impulsos del yo, y a los segundos, impulsos de la libido. En 1914 introdujo la idea de narcisismo y modificó la teoría de los impulsos instintivos ${ }^{24}$.

Gracias a los impulsos de autoconservación, el individuo logra adaptarse a la vida. Tales impulsos se caracterizan por ser muy poco flexibles, están casi del todo fijos. La satisfacción del hambre o de la sed, por ejemplo, son necesidades que no pueden posponerse indefinidamente; $y$ tampoco hay mucho margen de cambio en los modos de satisfacerlas: el agua, el oxígeno, ciertos nutrientes en los alimentos, son indispensables para la supervivencia humana, independientemente de los hábitos alimenticios de cada cultura.

La libido o los deseos sexuales, por el contrario, son más impulsivos y más bien suelen oponerse a lo que Freud denominó principio de realidad. Pasan años antes de que los impulsos libidinales se subordinen - al menos mínimamente- a las consideraciones realistas. A diferencia de los impulsos de autoconservación, los instintos sexuales son variables. Las modificaciones ocurren en lo relativo a la región del cuerpo, al objetivo y a la persona con quien se busca la satisfacción. Probablemente ésta sea la razón por la cual en torno a este tipo de impulsos giren tantos conflictos, sustituciones, desviaciones y perversiones.

Algunas veces, el impulso instintual se detiene en un punto y renuncia a su satisfacción completa. En este caso, el afecto puede manifestarse en el constante cuidado de la persona amada, sin obten-

28. Wolman, B., Introducción al conocimiento de Freud, México: Era, 1968, pp. 36-50.

29. Freud descubrió que el individuo puede orientar la libido hacia sí mismo y no necesaria y exclusivamente hacia los objetos externos. A ese fenómeno le dio el nombre de narcisismo. El narcisismo empieza, probablemente, en la vida prenatal y jamás desaparece por completo. El sano desarrollo de la personalidad exige una distribución armónica de los impulsos libidinales en sí mismo y en los demás. El descubrimiento del fenómeno del narcisismo derribó las barreras que separaban la libido de los instintos del yo. Llegó Freud a una interpretación monista de la vida instintual: no hay más que una fuerza de los instintos, la fuerza del amor, la libido, que puede invertirse en uno mismo —en el amor narcisista_, o bien, en los demás, en el amor con objeto, ibrd., pp. 44.45 . 
ción de placer sexual. A este proceso de suspensión de la satisfacción Freud lo llamaba inhibición del objetivo, del fin. El genuino amor de los padres tiene inhibición del fin, porque los padres amantes no esperan satisfacción sexual de sus hijos.

Se produce otra modificación en el despliegue de la sexualidad cuando se desvía la libido de la búsqueda del placer sexual por un canal socialmente útil; esta modificación es la sublimación. Freud creía que el arte creador representa este proceso de sublimación. Las energías puestas originalmente a disposición del sexo se subliman y orientan hacia otro canal de labor creadora, como las artes plásticas, la música o la literatura.

Uno de los descubrimientos básicos de Freud en materia de sexualidad fue que "la vida sexual comprende la función de obtener placer de algunas partes del cuerpo" (Freud), con independencia de la función reproductiva. Sostenía que los seres humanos tienden a procurarse el placer y evitar el dolor. Los instintos sexuales siempre siguen lo que él denominó principio del placer y, por ello - aunque la libido se manifiesta en múltiples formas-, éstos son el ejemplo más puro de los instintos vitales. "Freud unió bajo el nombre de Eros a todas las fuerzas que sirven al placer y exaltan las funciones vitales del individuo. Eros abarcó todos los impulsos sexuales y egoístas, y libido fue el nombre de todas las energías con que cuenta la potencia erótica" ${ }^{\text {30. }}$.

En un primer momento se pensó que la teoría de Eros y la libido podía explicar la amplia gama de los motivos humanos. Pero la brutalidad y el asesinato insensatos no encajaban en esa teoría, como tampoco lo hacían el sadismo, el masoquismo y el suicidio. Tales fenómenos llevaron a Freud a reconsiderar su teoría de los instintos. Después de dudar acerca de si los impulsos hostiles y los deseos de muerte formaban parte de la sexualidad, Freud terminó por agrupar tales impulsos bajo una categoría allende a Eros que recibió el nombre de Tanatos o "instinto de muerte".

El concepto freudiano de agresión se apoya firmemente en el principio general del equilibrio. De acuerdo con este principio, la naturaleza tiende a conservar su status quo y, cuando el equilibrio existente sufre un trastorno, la tendencia es a volver al estado anterior, el inicial. En consecuencia, el principio del placer debe entenderse como una tendencia que obra en función de cumplir con la aspiración más general de toda sustancia viva: volver a la quietud del mundo inorgánico.

A partir de entonces, la teoría freudiana de los instintos se basó en la pugna entre Eros y Tanatos, la cual fue explicada por Freud del modo siguiente: "Eros intenta aproximar y mantener unidas las porciones de sustancia viva... Nuestras especulaciones han sugerido que Eros opera desde el principio de la vida y aparece en forma de instinto de vida, por oposición al instinto de muerte surgido por el advenimiento de la sustancia inorgánica a la vida. Estas especulaciones tratan de resolver el enigma de la vida suponiendo que los dos instintos luchan uno contra el otro desde el comienzo de todo"'.".

La materia orgánica surgió a partir de la inorgánica. Pero, junto a la vida, nació un instinto que intentaba la vuelta al estado inorgánico; es decir, procuraba el aniquilamiento de aquello que acababa de surgir y que constituía, por tanto, un desequilibro. El fin de Tanatos es el restablecimiento de la naturaleza inanimada. La vida termina con la muerte, y la muerte conduce a una nueva vida. Eros y Tanatos están entrelazados; construcción y destrucción son inseparables. El proceso de la vida no puede quedar enteramente libre del instinto de muerte. "La cooperación y la oposición de estas dos fuerzas produce el fenómeno de la vida, al cual pone fir la muerte"?

En palabras de Freud: "tras largo dudar y vacilar hemos decidido dar por existentes dos instintos básicos, Eros y el instinto de destrucción... El fín del primero de estos dos instintos fundamentales es crear unidades cada vez mayores y conservarlas, o sea unir; el fin del segundo, al contrario, es deshacer los enlaces y, por lo tanto, destruir las cosas. Podemos suponer que el fin último del instinto destructor es reducir los seres vivos a un estado inorgánico. Por esta razón lo llamamos instinto de muerte" ${ }^{\text {"3. }}$. Es decir, "subrayaba Freud de preferencia el aspecto de la muerte, no el de asesinato. Morir es el

30. Ibid., p. 45.

31. Freud. 1920; citado en Wolman, B., 1968.

32. Freud, 1932; citado en Wolman, B., 1968.

33. Freud, 1938; citado en Wolman, B., 1968. 
fin inevitable de todo, la consecuencia ineludible del proceso de vivir. La muerte es el trágico fin de la vida, el destino definitivo de toda materia viva. Eros es la afirmación de la vida, Tanatos su aniquilación. El impulso sexual produce tensión para un alivio placentero, la muerte procura a todos los procesos vitales un pacífico final"14.

Si gracias a la tensión entre Eros y Tanatos tiene lugar la vida, es comprensible que, del mismo modo que estamos dotados de instinto de vida, lo estemos de instinto de muerte. Todos Ilevamos, pues, una dosis de autodestructividad dentro de nosotros. Ahora bien, la agresividad natural contra sí mismo puede dirigirse contra el mundo exterior. Es como si el ser humano sintiera la necesidad de desIruir cosas y personas para no aniquilarse a sí mismo. Con el tîn de protegerse de la tendencia a la autodestrucción, necesita hallar canales externos que le permitan desahogar su agresividad. "Cuando el comportamiento de un individuo se dirige, bajo el imperio de Tanatos, hacia el mundo de los demás, se convierte en agresivo y malévolo y difunde la destrucción y la muerte. Cuando esas fuerzas se dirigen contra uno mismo, entonces, el odio de sí mismo y el suicidio, o aniquilamiento de sí mismo, pueden poner lin a la vida"'s.

En definitiva, "todos los instintos resultan orientados hacia el restablecimiento de un estado de cosas anterior. En cuanto se trastorna un estado empieza una acción instintiva que apunta a restaurarlo. En esa acción combinan sus fuerzas Eros y Tanatos, pero no con menor frecuencia pelean uno contra otro. Comer es un proceso de destrucción con el fin de la asimilación; el coito es un acto de agresión que aspira a la más intima unión. Los impulsos sexuales raramente son nada más eróticos, y con mucha frecuencia se combinan en ellos empeños instintivos eróticos y destructores" ${ }^{36}$. Por lo demás, hay casos en los que los instintos destructivos vencen en la disputa y es, entonces, cuando se produce el sadismo o el masoquismo. En ambos casos, los impulsos agresivos rechazan los fines sexuales normales y predomina la necesidad de hacer daño al objeto de amor --sadismo-- o de sufrir y sentir dolor - masoquismo - para lograr la satisfacción sexual.

\subsection{El aporte de Erich Fromm}

Erich Fromm es, sin duda, uno de los más sobresalientes representantes de la tradición psicoanalítica. Fiel a las inquietudes de la Escue-
El concepto freudiano de agresión

se apoya en el principio general del equilibrio. De acuerdo con este principio, la naturaleza tiende a conservar su status quo y, cuando el equilibrio existente sufre un trastorno, la tendencia es a volver al estado anterior, el inicial. la de Frankfurt -de la cual formó parte en su etapa fundacional-_? se interesó especialmente por investigar los fundamentos biológicos, psíquicos y antropológicos de la agresividad humana. Su aporte teórico rescata los descubrimientos de Freud que permanecen vigentes $y$ que son útiles para la comprensión de la agresión; pero supone también una importante superación del planteamiento freudiano que se expuso antes.

Fromm inserta a Freud, junto con el reconocido etólogo Konrad Lorenz, dentro de la corriente instintivista ${ }^{3 k}$. Sostiene que, a pesar de las sensibles diferencias existentes entre sus respectivas teorías, ambos coinciden en concebir a la agresión como una fuerza inscrita en la estructura biológi-

34. Ibid., p. 49.

35. Ibid., p. 50.

36. Ibid., pp. 49.50 .

37. Ver Friedman, G., La filosofía políica de la Escuela de Frankfurt, México: FCE, 1986.

38. Tanto la teoría de Freud como la de K. Lorenz recibieron el calificativo de modelos "hidráulicos", por analogía con la presión ejercida por el agua o el vapor acumulados en un recipiente cerrado. Son modelos que conciben al organismo humano como una fuente inagotable de agresividad, sin considerar en lo absoluto los estímulos externos. Cuando la emanación llega a su punto más álgido ocurre una "explosión" que da lugar al comportamiento destructivo. Ver Fromm, E., Anatomia de la destructividad humana, Siglo XXI de España Editores, 1975. p. 33 y ss. 
ca del ser humano. Lo cual implica aceptar que la agresión es un instinto ineludible, contra el que nada puede hacerse. De acuerdo con el esquema instintivista: "el hombre estaba sometido al influjo de un impulso de destrucción de sí mismo o de los demás y no podía hacer gran cosa para escapar a esa trágica alternativa" ${ }^{19}$.

Pero no hay demostraciones empíricas que respalden la afirmación de que en todo organismo vivo, en toda materia orgánica, se halle presente una tendencia hacia la autodestrucción o hacia la destrucción de otros, diría Fromm ${ }^{411}$. A lo que añadiría, además, que Freud "oscureció mucho el análisis de la agresión" al subsumir todas las pasiones humanas en la dicotomía autoconservación-libido, primero, y Eros-Tanatos, después. Con la pretensión de explicar todos los impulsos acudiendo a uno solo de los dos instintos contemplados en su teoría, Freud terminó por agrupar tendencias que en realidad nada tienen que ver unas con otras ${ }^{4}$.

Resulta evidente, pues, que a Fromm le incomoda la idea según la cual la destructividad humana es innata y que, por consiguiente, nada se puede hacer para contrarrestarla. Valiéndose de estudios neurofisiológicos, etológicos, paleontológicos y antropológicos cuestiona contundentemente la concepción instintivista de la agresión. La tesis de Fromm dice que: "la agresión y la destructividad no son impulsos dados biológicamente y de fluir espontáneo". A continuación veremos los argumentos en que se apoya para sostener tal afirmación, por un lado; y su propuesta alternativa, por el otro.

De sus análisis científicos concluyó Fromm que: (a) si bien es cierto que hay, tanto en el ser humano como en otras especies superiores, ciertas zonas en el cerebro encargadas de las respuestas agresivas, éstas sólo se estimulan en función de la conservación de la vida y de las necesidades biológicoadaptativas del individuo y/o de la especie. Por otra parte, hay que añadir que el impulso de huida también está presente en la estructura fisiológica del ser humano, en la misma medida - sino en mayoren la que lo está la predisposición hacia el ataque. ¿Por qué en el ser humano predominan las reacciones agresivas sobre las de huida, siendo que esta última está igualmente inscrita en su naturaleza? Es a lo que Fromm intentará dar respuesta a lo largo de la argumentación que resumiremos más adelante.

(b) Por analogía con el comportamiento animal, se suele ver en fenómenos como el hacinamiento, el territorialismo y la dominancia caldos de cultivo para la generación de conductas agresivas. Sin embargo, habrá que decir, con respecto al hacinamiento, que mientras el animal no tiene muchas posibilidades de modificar su entorno, el ser humano puede "cambiar la estructura social, crear lazos de solidaridad y de valores comunes por encima de lo que le es dado instintualmente. La solución del animal al hacinamiento es biológica e instintiva; la del hombre es social y política"42. De los fenómenos restantes, territorialismo y dominancia, resulta muy difícil probar que sean hechos objetivos. Puede decirse, más bien, que son rasgos que comparten determinadas especies, en condiciones especiales en las que se pone en riesgo la supervivencia o la adaptación al medio que se ha puesto en riesgo.

(c) Otro supuesto que favorece la tesis instintivista es el que considera al ser humano como un

39. Ibid., p.31.

40. Para una refutación detallada del instintivismo ver la segunda parte de Anatomía de la destructividad humana, titulada "Pruebas contra la tesis instintivista", ibid., pp. 101-188.

41. Ibid., p. 32.

42. Ibid.. p. 120. 
depredador. Para la refutación de este punto son útiles los estudios paleontológicos que han demostrado que la dieta de los ancestros del ser humano -Ramapithecus, Australopithecus - era predominantemente vegetariana. "Los homínidos no fueron animales depredadores con la dotación instintual y morfológica que caracteriza a los depredares carnívoros como el león o lobo... Nada hay que justifique la suposición de que el australopiteco tuviera los instintos de un animal rapaz que, en caso de que fuera él el antepasado del hombre, pueda ser el causante de que el hombre tenga genes de 'depredador"'4?.

(d) Pensar en lo determinante que ha sido la caza en la evolución humana también ha llevado a sostener que en el hombre existe una predisposición natural a sentir placer por la muerte y la tortura. Pues bien, quienes así argumentan olvidan que el placer que los hombres primilivos experimentaban al cazar obedecía más a la satisfacción que traía el dominio de una destreza, que al desahogo de un impulso sádico, biológicamente predeterminado.

De igual modo podría argüirse en contra de quienes ven el interés de los niños en el aprendizaje del dominio de armas o artes marciales, por ejemplo - por lo demás, muy similar al entusiasmo que presentan éstos por ciertos deportes u otras habilidades artísticas-, una demostración de la naturaleza innata de la agresividad. Lo que llena a esos niños de satisfacción es poder manejar un artefacto -o su propio cuerpo- diestramente y no la idea de matar o torturar a alguien con él.

(e) Finalmente, cabe mencionar otro argumento contra la tesis instintivista y es el que se apoya en la antropología. Basándose en su análisis de 30 tribus primitivas, Fromm asegura que la relación entre el nivel de civilidad y la destructividad es inversa y no directa. Resulta que, contradiciendo la idea inmensurablemente generalizada de que a menor grado de civilización mayor salvajismo y destructividad, Fromm pone en evidencia que "los recolectores, cazadores inferiores y agricultores inferiores son los menos guerreros. Los cazadores superiores y agricultores superiores son los más belicosos, y los agricultores más importantes y los pastores superan a todos en belicosidad"44.

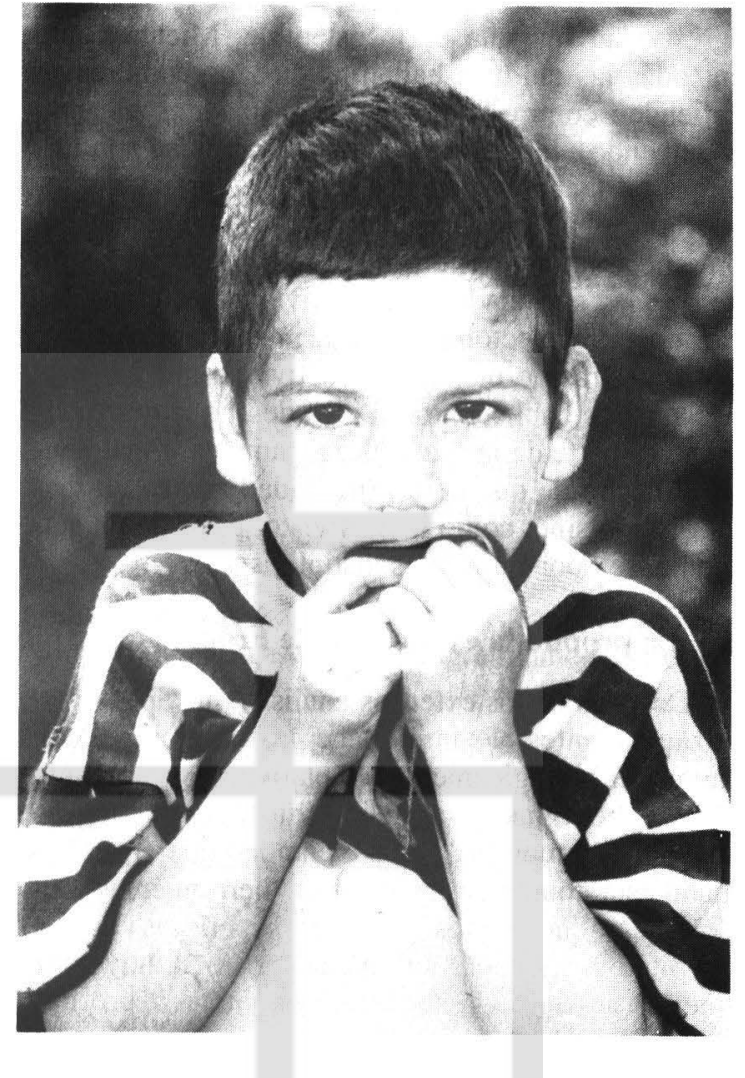

"Los datos de Wright —añade Fromm- muestran que cuanto mayor es la división del trabajo en una sociedad, tanto más belicosa es ésta, y que las sociedades con sistemas de clases son las más guerreras de todas. En definitiva, estos datos señalan que cuanto mayor es el equilibrio entre grupos y entre el grupo y su medio físico, menor es la belicosidad, mientras que los trastornos frecuentes del equilibrio tienen por consecuencia el aumento del espíritu guerrero... Los datos de Wright confirman la tesis de que los hombres más primitivos son los menos guerreros, y que la belicosidad aumenta a medida que aumenta la civilización. Si la destructividad fuera innata en el hombre, la tendencia hubiera sido a la inversa"45.

Para concluir esta parte de su planteamiento. Fromm reafirma: "los datos antropológicos han demostrado que la interpretación instintivista de la

43. Ibid., pp. 137, 138.

44. Wright, Q., 1965; citado en Fromm. E., 1974.

45. Ibid., pp. 158, 159. 
agresividad humana es insostenible. Mientras que en todas las culturas hallamos que los hombres se defienden contra las amenazas a su vida peleando (o huyendo), la destructividad y la crueldad son mínimas en tantas sociedades que estas grandes diferencias no podrían explicarse si estuviéramos en presencia de una pasión 'innata'. Además, el hecho de que las sociedades menos civilizadas, como los cazadores recolectores y los primeros agricultores, den muestras de menos destructividad que los más adelantados habla contra la idea de que la destructividad es parte de la 'naturaleza' humana. Finalmente, el hecho de que la destructividad no sea un factor aislado sino, como hemos visto, parte de un síndrome, se opone a la tesis instintivista"46.

\subsection{La propuesta explicativa de Fromm}

Después de los extensos análisis, que apenas esbozamos antes, Fromm hace la distinción entre "agresión biológicamente adaptativa, favorable a la vida y benigna, y agresión biológicamente no adaptativa y maligna"47. Se mencionó que el ser humano está dotado de las mismas "herramientas" fisiológicas que ciertos animales superiores, que le permiten responder, ya sea atacando o huyendo, ante las amenazas a sus intereses vitales. Pero hay un rasgo determinante a la hora de establecer diferencias entre el ser humano y las demás especies: el hombre es el único animal para el que la muerte y la destructividad pueden convertirse en un fin en sí mismo; puede causar placer en quien la ejerce y puede volverse, inclusive, biológicamente perjudicial.

Podría decirse que la explicación de este segundo lipo de agresividad es el motivo fundamental de los análisis de Fromm. Su tesis básica es que la hiperagresión del ser humano —en nada semejante a la agresividad instintual de los animales - radica en las condiciones existenciales del hombre. Pero antes de entrar a la explicación de ésta, conviene detenerse un poco en sus consideraciones acerca de la agresión benigna. A este respecto, el autor propone toda una tipología que no viene al caso detallar aquí. Tal vez convenga sólo precisar que, dentro de esta categoría, Fromm establece la subdivisión entre seudoagresión y agresión defensiva. En la primera rama ubica a aquellos tipos de agresión cuyo objetivo no es causar daño o destruir al propio individuo o a otros; entre estos tipos tenemos: la agresión accidental, la agresión por juego, la agresión en tanto autodeterminación, decisión, "empuje", para llevar a cabo y a buen término una meta.

A la agresión defensiva ${ }^{48}$ pertenecen: la agresión que atenta contra la libertad -en tanto que la libertad, individual y social, ocupa un lugar preponderante entre los intereses vitales -; el narcisismo y la resistencia como desencadenantes de la agresión; y la agresión instrumental ${ }^{44}$, dentro de la cual se inserta la guerra.

Especialmente interesante resulta el que Fromm incluya al narcisismo y a la resistencia -categorías eminentemente psicoanalíticas- entre la serie de “agresiones benignas". Se entiende aquí que, a pesar de su carácter patológico —o precisamente en virtud de ello-, las amenazas contra el narcisismo equivalen a amenazas a intereses vitales, en tanto las necesidades de aplauso y veneración de un narcisista se convierten en requisitos para la preservación de su estabilidad emocional. Con la resistencia sucede otro tanto. Para un individuo, mantener ocultas sus motivaciones inconscientes es de tal importancia para su estabilidad, que cualquier intento por hacerlas aflorar puede desencadenar en él altas dosis de agresividad.

Vayamos ahora a las consideraciones de Fromm acerca de la agresión maligna. Quizá lo más importante del aporte de este autor al respecto sea haber extraído la destructividad del ámbito de potencialidades innatas e inamovibles, para ubicarla en el área de las condiciones de la existencia humana. Pero, ¿qué quiere decir condiciones existenciales del ser humano? Pues bien, son todos aquellos fac-

46. Ibid.. p. 185.

47. Ibid.. p. 193.

48. En este punto cabe enfatizar en las diferencias entre el ser humano y el animal. Mientras que la acción defensiva de este último se encuentra fijada en su estructura biológica, el hombre es el único que puede: prever una posible situación de amenaza, a futuro, y ser manipulado o inducido a pensar que está amenazado, o que puede estarlo, sin que tal situación de riesgo exista objetivamente, ibid., pp. 201, 202.

49. En la cual, como se vio ya en las primeras páginas del presente trabajo, el dañar a otros no es visto como un fin, sino como un medio para obtener lo que se desea o se necesita. Es el caso del drogadicto capaz hasta de matar para conseguir su dosis, aunque el interés primigenio de su agresividad no coincida con el de un asesino. Ibíd. p. 214. 
tores que le permiten ser, desplegar sus potencialidades, desartollarse, crear, construir. Pero, justamente por su capacidad creadora, el ser humano es capaz de hacer lo que ninguna otra especie: construir sus propias condiciones de posibilidad, reinventar nuevas alternativas para modificar su existencia, su manera de estar en el mundo, de hacer cosas, de sentirlas.

En esta forma peculiar del hombre de estar en el mundo es que deben entenderse las pasiones humanas. La capacidad de amar, odiar, envidiar, admirar... son cualidades específicamente humanas. Forman parte inherente de su humanidad, son las pasiones en virtud de las cuales la vida adquiere sentido $^{\text {"). }}$. Por ello son tan o más determinantes que las necesidades fisiológicas a la hora de configurarse la personalidad y la estructura social. El hombre no ha alcanzado los niveles de civilización que ha alcanzado gracias una suerte de determinación biológica, sino más bien debido al ejercicio de su posibilidad de optar, de tomar alternativas, de crear. Y esas decisiones y alternativas nuevas están condicionadas por pasiones y deseos: deseos de dominación, deseos de un mundo mejor, deseos de mayor libertad o de mayor opresión.

Con demasiada frecuencia el ser humano encuentra en la crueldad y destructividad los motivos que dan sentido a su existencia. En el ser humano se hallan presentes tanto deseos amantes de la vida, biófilos, como impulsos propensos a la muerte, necrófilos. Esta es una consideración muy similar a la dicotomía freudiana Eros-Tanatos, con la diferencia de que para Fromm los impulsos destructivos o necrófilos no pertenecen a la "naturaleza humana", no están inscritos en su biología, sencillamente porque lejos de contribuir a la supervivencia y el lortalecimiento del individuo y de la especie, tienden a eliminarlos, debilitarlos y dañarlos. Mientras que para Freud el instinto de destrucción era una fuerza inherente al organismo, imposible de combatir, para Fromm los impulsos destructivos, si bien pueden llegar a formar parte - y lo hacen de hecho- de las necesidades más elementales del hombre, el carácter de tal necesidad es psíquico y, por ende, se encuentra considerablemente determinada por patrones sociales y culturales.
Ahora, al igual que para la agresión benigna, Fromm establece para la agresión maligna una tipología particular, agrupada en las categorías: destructividad aparente - a la cual pertenecen las formas agresivas cuya motivación primordial es el culto religioso u otro similar, y no la salisfacción sádica-; las formas espontáneas —entre las cuales se encuentran tanto el deseo de venganza como la destructividad en tanto vía fácil hacia el éxtasis- y, por último, el carácter destructivo. Podría asegurarse que éste último es el más grave de todos los modos posibles de agresión maligna ya que, en este caso, la destructividad forma parte de los rasgos de carácter del individuo $\longrightarrow$ del grupo social-; es decir, la persona no puede ser sin destruir, la destrucción es condición necesaria de su equilibrio emocional - en caso de que logre mantenerse equilibrado.

Sadismo y necrofilia son las formas del carácter destructivo ${ }^{51}$. La característica fundamental del sadismo es la necesidad de dominio sobre otro ser humano. El sádico necesita demostrar su poder

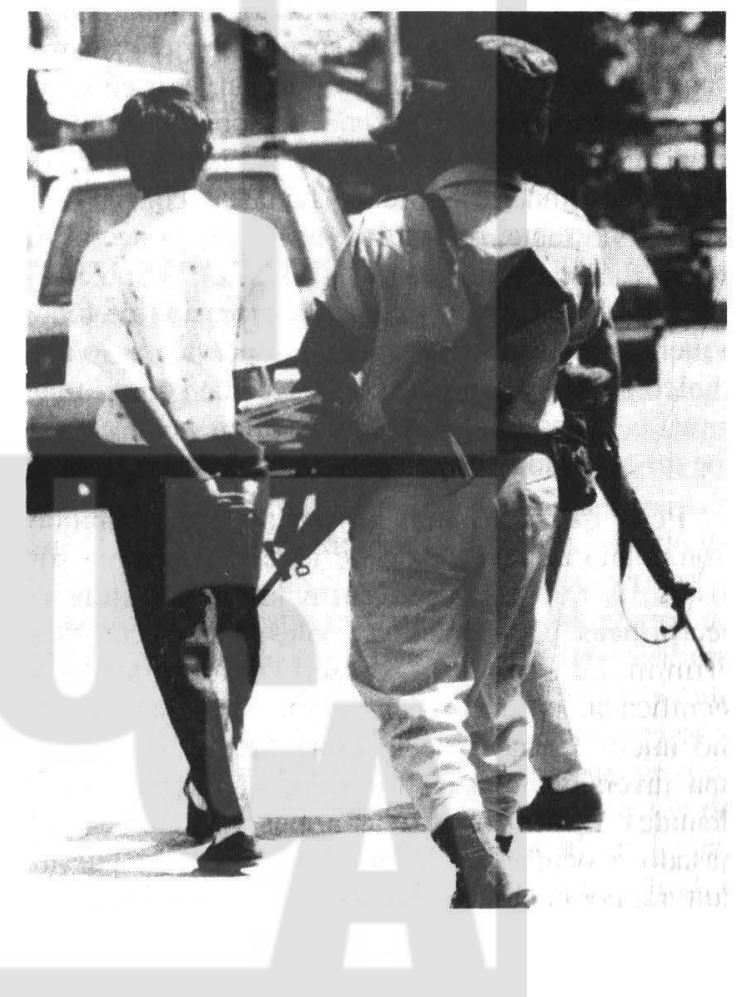

50. Hidd. p. 23.

51. Cabe aclarar que no se está haciendo referencia exclusiva al sadismo y la necrofilia sexuales, aunque ciertamente estos constituyen modos muy comunes y reconocidos del carácter destructivo. 
frente a alguien más débil e indefenso que él porque en el fondo se siente miserable, no deseado, débil e impotente. Cree que dominando a otros se engrandece, pero mientras está frente a alguien más poderoso que él su sumisión es ilimilada. Asimismo depende de modo enfermizo de quien padece su dominación que, principalmente en el caso del sadismo sexual, es el masoquista.

El masoquista necesita ser dominado tanto como el sádico necesita dominar porque la base de ambas necesidades es la misma: el sentimiento de impotencia, la sensación de que carecen de vida y de poder. Ninguno de los dos puede sentirse satisfecho o "completo" sin hacer padecer o sin sufrir padecimiento 5 . Himmler y Stalin son ejemplos culminantes de sadismo. El análisis de sus respectivas personalidades evidencia su necesidad compulsiva de infringir daño a otros, de torturar y, sobre todo, de sentir que la vida de los demás les pertenece absolutamente, que tienen potestad infinita sobre la vida y la muerte de los otros.

La necrofilia, el otro rasgo del carácter destructivo, es el amor por todo lo muerto, lo inanimado y lo putrefacto. Al igual que sucede con el sadismo, pero sin duda con menor proporción, existen casos clínicos de necrofilia sexual, personas que no logran la satisfacción sexual si no se hallan cerca de - o con- muertos o tienen fantasías con cadáveres. No obstante, reviste mayor interés la necrofilia como fuente de rechazo a la vida, de desprecio a todo lo vital. La necrofilia es la expresión de todos aquellos impulsos que tienden a supervalorar lo mecánico sobre lo espontáneo, lo técnico sobre lo natural, la muerte sobre la vida. Hitler, por ejemplo, fue un caso paradigmático y crítico de necrofilia.

Pero quizá lo más importante del análisis frommiano de este modo de agresión maligna son los lazos que establece entre las personalidades necrofílicas y las raíces sociales de la necrofilia. Fromm cuestiona la sociedad automatizada, lecnilicada, producto del desarrollo científico que dio inicio a finales de la Edad Media. Ha habido una inversión total en los valores culturales occidentales. Las máquinas, las armas y la técnica han pasado a ocupar un lugar privilegiado en nuestra cultura, por cncima de las acciones que defienden la vida, la sensibilidad, la alegría y la esperanza. El diagnóstico de Fromm es que vivimos en una sociedad necrofílica en la que la vida, en tanto que valor, va perdiendo cada vez más espacio y, por consiguiente, sentido.

No hay, pues, que extrañarse de que dentro de ella se produzcan individuos que alaben la muerte, que prefieran la destrucción y desprecien la vida hasta el punto de no presentar inconvenientes en acabar con ella. Obviamente, esta forma de vivir, estos valores, impactan negativamente a las personas. Cada vez resulta más difícil encontrar razones para estar vivos y disfrutar de ello, pero este hecho ensancha el umbral de posibilidades de generar agresión. Se forma entonces una espiral de sin sentidos, un círculo vicioso en cuyos ejes se hallan la muerte y la destrucción.

\subsection{Valoración crítica}

Sin duda, el aporte fundamental de Erich Fromm al estudio de la agresividad, de la violencia humana, es haber cuestionado tan contundentemente la tesis instintivista. Si bien es innegable que la teoría de Freud implicó un sustancial avance respecto de los instinvistas prefreudianos, ésta no logró salir del horizonte biologicista según el cual todo cuanto acontece en el ser humano encuentra sus causas en la estructura biológica de la que fue dotado por el proceso de evolución. Aún así hay que recunocer que fue Freud quien descubrió que tanto el instinto de vida como el instinto de muerte forman parte determinante en la configuración del individuo y explican sus más hondos motivos. En ello no se equivocó. En lo que sí lo hizo fue en haber entendido a Tanatos como un instinto, como un condicionante biológico.

Fromm pone de manifiesto la determinación cultural en la configuración de la personalidad y con ello da un salto cualitativo en la comprensión de la agresión: la destructividad no es un impulso o fuerza incontrolable dentro del ser humano, sino parte de la configuración histórica de las sociedades. El hombre, en tanto que especie, no nació destructivo, no llevaba dentro de sí los genes de la crueldad cuando llegó al mundo; más bien la forma en la que se fue desarrollando en él, su deseo de dominarlo y comprenderlo, de crear, de posicionarse frente a las cosas, lo llevó a generar

52. Los padres que causan daño lísico o psicológico a sus hijos, los burócratas o funcionarios que gozan ejerciendo su restringido poder sobre los usuarios son, de acuerdo con Fromm, expresiones de sadismo no sexual. 
formas destructivas de convivencia. $Y$ eso no significa otra cosa si no que la historia, en tanto construcción de posibilidades de existencia, pudo haber sido de otra manera, y aún hoy, puede llegar a modificarse, si así lo decidieran los hombres.

Entramos aquí a la parte utópica del planteamiento frommiano. Cabe señalar que tal planteamiento tiene fuerte influencia marxista. De hecho, Fromm cita a Marx en sus consideraciones, cosa que no deja de ser llamativa. Se podría decir que el planteamiento de Fromm hace un esfuerzo por conciliar dos polos teóricos, aparentemente disímiles en grado sumo: la explicación de las conductas y motivos individuales, el psicoanálisis, con la explicación macro de las motivaciones e intereses del todo social, el marxismo.

Recordemos que Freud propone como palialivo de las conductas agresivas la canalización de la libido hacia las ramas creadoras como el arte. Pues bien, Fromm irá mucho más lejos al proponer un cambio radical en la sociedad, al plantear la necesidad de la lucha por un orden social en el que la dominación de unos sobre otros desaparezca y los valores que pugnan por la muerte sean reemplazados por los que pugnan por la vida. Dice Fromm, al referirse a las condiciones para la reducción de la agresión defensiva: "habrá que idear formas enteramente nuevas de descentralización, así como nuevas estructuras políticas y sociales que acaben con la sociedad de anomia, la sociedad de masas compuesta por millones de átomos" ${ }^{\text {? }}$ ?

Fromm postula esta "ulopía" en el marco de la reflexión sobre la agresión defensiva en la cual inserta a las rebeliones. Los pueblos se revelan cuando sus necesidades vitales han sido violentadas $y / 0$ insalisfechas. Pero, aún así, ¿qué quiere decir exactamente con habrá que idear? ¿Quién habrá de hacerlo? ¿Las autoridades políticas y sociales a quienes más bien les favorece el mantenimiento del status quo? ¿O los ciudadanos a quienes parece impor- tarles cada vez menos lo que vaya a ser de su futuro?

Como sea, el planteamiento utópico de Fromm, aunque consecuente con su punto de vista - la historia es una construcción social, hasta cierto punto, independiente de las modificaciones-, da lugar a serias dudas con respecto a las posibilidades reales de llevarse a cabo. Parte de las inquietudes del horizonte posmoderno tienen que ver justamente con la incertidumbre acerca del futuro y con las dudas que suscitan las posibilidades reales de un mundo mejor, más humano, etc. No se está queriendo aquí hacer una defensa de las posiciones que con su total pesimismo rayan en el conformismo paralizante. De lo que se trata es de cuestionar esas vagas formulaciones de los teóricos que, habiendo hecho atinados diagnósticos de la sociedad, culminan sus trabajos con frases como "hay que implementar", "todos debemos contribuir a", "es necesario cambiar"; frases, por lo demás, casi siempre inútiles.

No obstante, Fromm nos ha dado la posibilidad de ver que la destrucción y la crueldad no pertenecen a la natura. leza humana y que, por lo tanto, no serían estériles los intentos de minimizarla. La idea de que no hay nada que pueda hacerse contra la destructividad, porque ella está inscrita en los genes, resulta idónea para esconder los verdaderos desencadenantes culturales de las conductas hostiles. Que la destructividad se haya complejizado junto con el desarrollo de la civilización es un dato sumamente sugerente y revelador. Demuestra justamente que los grados de civilización alcanzados han exigido destrucción, muerte y dominación. Las guerras se inician ante todo por motivos políticos, sociales o económicos y no por la necesidad biológica de los pueblos de desahogar su potencial destructivo. La historización de la destructividad permite observar que el ser humano no está inexorablemente destinado a ser cruel, a dominar, a ser dominado o a destruirse a sí mismo $o$ a otros.

53. Ibid., p. 221. 
Es inevitable, sin embargo, preguntarse, llegados a este punto, qué tantos deseos pueden detectarse en la humanidad de querer modificar radicalmente su modus vivendi actual. En el caso hipotético de que llegara a aceptarse, junto con Fromm, que la destructividad puede abolirse, $o$ al menos reducirse, surge la pregunta de si querrá hacerlo el ser humano. ¿No parecen ser más los que están dispuestos a aferrarse al sistema de valores predominante que los que luchan por una cultura de la vida?

Frente a tal inquietud, Fromm plantea la propuesta de la fe. Pero no de una fe de carácter religioso, sino una fe como expresión del genuino deseo de que el mundo pueda ser mejor, de que los hombres puedan superar su propensión a la destructividad. La fe involucra, invita a sentirse parte en la construcción del proceso de esa superación. Lastimosamente el eco de la necrofilia parece retumbar cada vez con mucha mayor fuerza, que el eco esperanzado y amante de la vida que defendiera Fromm hace dos décadas.

Algo en lo que conviene detenerse un poco antes de terminar es en la distinción entre agresión benigna y agresión maligna, distinción que es el pilar en el que se basa Fromm para efectuar una relativización histórica de la destructividad. Se entiende que tal divorcio es primordialmente analítico y resulta de suma utilidad para demostrar la hipótesis frommiana. El mismo está consciente de que lo que separa a ambas agresiones no es una frontera inexpugnable. En ciertos pasajes menciona, por ejemplo, que después de haber puesto en práctica la agresión defensiva - benigna, en principio- ya se ha roto el umbral de la agresividad y resulta más fácil propender a acciones destructivas biológicamente no adaptativas, malignas.

Pero, a excepción de estas aclaraciones esporádicas, consideramos que Fromm no profundiza lo suficiente en el problema de la fragilidad del límite entre los dos tipos de agresión que él distingue. Es bien sabido que una guerra puede ser todo lo instrumental que quiera ser o todo lo defensiva posible, pero los mismos sujetos que la llevan a cabo pueden, en cierto momento, empezar a experimentar placer con matar o torturar a sus enemigos. La agresión en un primer momento "benigna" se transformaría de repente en "maligna", lo cual sucede de hecho y con demasiada regularidad. Podrían darse innumerables ejemplos para evidenciarlo.

Sería necesario, pues, examinar detenidamente nuevos estudios sobre la agresión para ver si algo se ha avanzado a respecto que, por lo demás, podría poner serias cortapisas a la formulación frommiana. Esto en el sentido de que si bien la destructividad humana es una característica más de su modo de ser civilizado, ahora que la engendró ya no puede deshacerse de ella porque no está dispuesto a abandonar el crucial descubrimiento de que, así como puede servirle para conservarse a sí mismo y a la especie, puede serle útil para dominar y extraer una gran variedad de beneficios - materiales y espirituales. Nada definitivo se puede decir aquí en este sentido, excepto que lo más deseable es que Fromm tenga razón, aunque pocos parezcan estar dispuestos a tomarlo en serio por ahora.

\section{Conclusión}

La revisión teórica anterior nos permite plantear las conclusiones siguientes.

1. La violencia no tiene porqué ser asimilada con prácticas brutales, como asesinatos, secuestros o violaciones. Estas prácticas ciertamente son violentas, pero no la agotan, no sólo porque existen prácticas mucho más aberrantes que las señaladas -la tortura de niños o los genocidios, por ejemplo-, sino porque las hay más sutiles - los cambios de voz para inducir a otros a comportarse de determinada manera- e incluso, las hay que pueden ser vistas como "constructivas" - los rasguños de los amantes en pleno éxtasis amoroso. La violencia, entendida como un ejercicio de fuerza padecido por individuos o grupos, no se agota en ninguna de las manifestaciones puntuales en que se concreta.

2. Por lo anterior, la violencia, antes de ser buena o mala, saludable o patológica, es una realidad presente inexorablemente en la convivencia humana: Ya sea que aceptemos que su naturaleza es social, subjetiva (psico-biológica) o ambas a la vez, su realidad es algo que va más allá de la voluntad de los individuos. Se trata, entonces, de aprender a convivir con la violencia, tanto con la que dimana de la naturaleza humana como con la generada por las estructuras sociales, políticas y económicas. Ahora bien, aprender a convivir con la violencia no significa hacerlo con un tipo determinado de violencia, sino algo mucho más profundo: vivir con la conciencia de que los seres humanos ejercen fuerza sobre otros muchas veces para realizar fines intimos que les son desconocidos a ellos, y muchas otras - las más evidentes- para 
obtener algunos bienes simbólicos o materiales. Entre la presión de las estructuras y la presión de su naturaleza psicobiológica, existe un resquicio en el cual el individuo puede no abolir la violencia, sino transformar algunas de sus concreciones más nocivas para él y la especie humana en algo menos dañino $o$, incluso, más constructivo.

3. La violencia tiene dos dimensiones esenciales, una instrumental y otra expresiva. Ambas dimensiones permiten agrupar los diversos tipos de violencia conocidos hasta ahora. Así, es factible agrupar en el primer ámbito no sólo la mayor parte de casos de violencia criminal (tipificados como tales en la legislación penal), sino todos aquellos casos, no penalizados e incluso aceptados socialmente, en los que se utiliza la fuerza (un profesor que grita a un estudiante, un conductor que se adelanta a otro, un padre tirando de las orejas de su hijo) para obtener un bien externo como resultado de ello. En el segundo ámbito se pueden agrupar los diversos tipos de violencia en los cuales, tras el ejercicio de la fuerza, el bien externo es sumamente oscuro $\longrightarrow$ mínimo en relación con la fuerza empleada -, siendo particularmente fuerte la emotividad (sexual, ideológica o religiosa) mostrada por el individuo o grupo ejecutor.

4. Entre ambas dimensiones de la violencia expresiva e instrumental- se puede establecer una cierta primacía de la violencia expresiva. Esta, en efecto, puede ser considerada como la principal violencia - en el sentido de que hunde sus raíces en la individualidad humana, biológica y psicológica - siendo la instrumental una oportunidad para su manifestación. Si aceptamos esta tesis, hemos de aceplar que en todos los casos de violencia instrumental, aun en los más nítidamente intrumentales, siempre está presente -alimentándolos - la carga de violencia psicobiológica que lleva consigo todo individuo. Es decir, que aun el ladrón más frío y calculador está dominado más que por el afán de conseguir la joyas o el dinero, por un ansia (no siempre consciente) de expresar, en su robo frío y calculado, la carga de violencia que lleva internamente consigo. Por tanto, a esta carga de violencia, a sus raíces y vías de expresión es a las que tendrían que prestar atención todos aquellos preocupados por el auge de la violencia destructiva en la sociedades actuales.

5. La agresividad está presente en nuestra estructura filogenética y su función primordial es contribuir a la defensa de los intereses vitales del individuo y de la especie. Esta agresividad tiene múltiples manifestaciones $y$, de hecho, gran parte de ellas es deseable y/o necesaria. Sin agresividad autoafirmativa, por ejemplo, el individuo tendría problemas para forjarse una identidad propia para defender sus propios puntos de vista, para lograr sus objetivos y alcanzar sus metas.

6. La agresividad biológicamene no adaptativa o maligna suele ser perjudicial tanto para quien la padece como para quien la infringe. Tiende hacia la muerte y la autodestrucción y su origen se enraíza en la historia de la humanidad y no en la estructura biológica de la especie humana. Esto significa que existe la probabilidad de que este tipo de agresión destructiva sea minimizada. No obstante, eso no garantiza que las sociedades actuales - tal y como están configuradas en la actualidad- estén dispuestas a crear las condiciones para que eso suceda.

7. Para una comprensión más cabal de este fenómeno valdría la pena establecer una distinción terminológica, al menos entre los conceptos agresión, violencia y destructividad. Lo que en un sentido más sociológico suele conocerse como violencia, no puede equipararse al mecanismo agresivo con el que biológicamente están dotadas las especies superiores para lograr su conservación. Como se ha analizado aquí, la crueldad y destructividad son características específicas del ser humano y poseen dinamismos propios, ajenos en muchos aspeclos a las determinaciones biológicas. La pretensión de estigmatizar todo bajo la categoría de violencia tiende a oscurecer la comprensión de la misma. Por ello, la caracterización de cada uno de estos términos sería un útil material en el avance de la aproximación teórica al fenómeno de la violencia.

San Salvador, 1 de octubre de 1998. 